\title{
Irrigation Levels and Abscisic Acid Effects on the Yield and Fruit Quality of Strawberry
}

\author{
Burçak Kapur $^{1 *}$, Eser Çeliktopuz ${ }^{2}$, Mehmet Ali Sarıdaş $^{3}$, Abdul Qaiyom SARWARI $^{4}$ \\ 1* University of Cukurova, Faculty of Agriculture, Agricultural Structures and Irrigation Department, 01330, Sarıcam/Adana, Turkey, (ORCID: 0000-0001-6131-4458), \\ burcakkapur78@gmail.com \\ ${ }^{1}$ University of Cukurova, Faculty of Agriculture, Agricultural Structures and Irrigation Department, 01330, Sarıcam/Adana, Turkey, (ORCID: 0000-0002-5355-1717), \\ eceliktopuz@gmail.com \\ ${ }^{2}$ University of Cukurova, Faculty of Agriculture, Horticultural Science Department, 01330, Sarıcam/Adana, Turkey, (ORCID: 0000-0002-5180-1874), \\ masaridas@gmail.com \\ ${ }^{1}$ University of Cukurova, Faculty of Agriculture, Agricultural Structures and Irrigation Department, 01330, Saricam/Adana, Turkey, (ORCID: 0000-0003-3468-380X), \\ abdul.qaiyom@gmail.com
}

(First received 10 August 2021 and in final form 3 November 2021)

(DOI: 10.31590/ejosat.981197)

ATIF/REFERENCE: Kapur, B., Çeliktopuz, E., Sarıdaş, M.A. \& Sarwari, A. Q. (2021). Irrigation Levels and Abscisic Acid Effects on the Yield and Fruit Quality of Strawberry. European Journal of Science and Technology, (33), 258-266.

\begin{abstract}
In this study, the effects of four irrigation regimes (IR125, IR100, IR75, and IR50) and Abscisic Acid (ABA) application on the cv. Rubygem strawberries, considering yield, and some fruit quality characteristics (Soluble solid content, fruit firmness, $\mathrm{pH}$, and color properties) were investigated under Spanish type-high tunnels in the Mediterranean region of Turkey. From March to May, 20 mol $\mathrm{L}^{-1}$ of Abscisic Acid was administered three times via foliar application. The treatments IR125, IR100, IR75, and IR50 received 712, 575, 438, and $301 \mathrm{~mm}$ of water, respectively, during the trial. The highest average yield per plant was obtained from the ABA x IR125 combination as 1124.5 (g/plant). It was determined that the ABA application increased the yield by approximately $8 \%$, although it was not statistically significant compared to the control conditions. In addition to this, abscisic acid applications had no statistically significant influence on $\mathrm{pH}$, fruit color, fruit firmness, or fruit weight parameters, while SSC parameters were statistically significantly affected. Based on our findings, it is expected that the IR125 and IR100 irrigation applications will be applied more frequently in future investigations. Furthermore, the findings suggest that combining ABA with the proper amount of irrigation water, as well as ABA applications in water stress or multiple stress circumstances, may be useful in increasing plant adaptation capacity.
\end{abstract}

Keywords: Mediterranean Region, Fruit Firmness, Rubygem, Soluble Solid Content, High Tunnel

\section{Çilekte Verim ve Meyve Kalitesi Üzerine Sulama Seviyeleri ile Absisik Asit Uygulamalarının Etkileri}

$\ddot{O} \mathbf{z}$

Çalışmada, Türkiye'nin Akdeniz bölgesin ikliminde İspanyol tipi yüksek tünel altında Rubygem çilek çeşidi üzerinde dört sulama rejimi (IR125, IR100, IR75 ve IR50) ve absisik asit (ABA) uygulamasının verim ve bazı meyve kalite özellikleri (Suda çözünebilir kuru madde, meyve sertliği, $\mathrm{pH}$ ve renk özellikleri) açısından etkileri araştırılmıştır. Absisik asit $20 \mu \mathrm{mol} \mathrm{L}{ }^{-1}$ olacak şekilde Mart ayından başlayarak, Mayıs'a kadar 3 kez yapraktan uygulanmıştır. Çalışma boyunca; sırasıyla toplamda 712, 575, 438 ve $301 \mathrm{~mm}$ su IR125, IR100, IR75 ve IR50 konularında uygulanmıştır. Bitki başına en yüksek verim ABA x IR125 kombinasyonundan 1124.5 $\mathrm{g}$ /bitki olarak elde edilmiştir. Kontrol grubu ile karşılaş̧ırıldığında istatistiksel olarak önemli olmamasına karşın, ABA uygulamasının verimi yaklaşık \% 8 düzeyinde arttırdığı belirlenmiştir. Bununla birlikte $\mathrm{ABA}$ uygulaması meyve kalite parametrelerinden $\mathrm{pH}$, meyve rengi, sertliği ve ağrılığı üzerine istatistiksel açıdan önemli etki yapmazken, suda çözünebilir kuru madde içeriğinin önemli düzeyde geliştiği belirlenmiştir. Bulgular doğrultusunda, gelecekteki çalışmalarda IR125 ve IR100 uygulamalarının daha sık uygulanacağı beklenmektedir. Bunlarla birlikte, bulgular su stresi veya çoklu stres durumlarında uygun miktarda sulama suyuyla yapılan ABA uygulamasının bitkinin adaptasyon kapasitesi için faydalı olabileceğini önermektedir.

Anahtar Kelimeler: Akdeniz Bölgesi, Meyve Sertliği, Rubygem, Suda Çözünebilir Kuru Madde, Yüksek Tünel 


\section{Introduction}

Droughts are anticipated to become more frequent and last longer as a result of climate change in different parts of the world, including the Mediterranean region. The challenges that may arise in agricultural production in terms of food safety are expected to create significant problems in this content. Understanding the effects of water stress on plants is critical for developing solutions to reduce water stress and its severe consequences for agriculture's future. Therefore, the evaluation of different irrigation regimes and increasingly widespread practices for sustainable agriculture such as Abscisic Acid (ABA) application, can help to increase yield and fruit quality, control fruit ripening in plants, regulate photosynthetic enzymes and root growth in saline conditions, promote more water uptake and plant growth. Thus, these natural and environmentally friendly practices may increase tolerance to abiotic and biotic stresses such as water stress, reduce transpiration to prevent water loss, and help stomatal closure.

Strawberry, with its high adaptability, is a widely cultivated and most consumed type of berry fruit. (Ağaoğlu \& Gerçekçioğlu, 2013). Another key factor that contributes to strawberry cultivation's relevance is that it is essential for human health and nutrition (Maas and Ark, 1996). Strawberry is a high-fiber fruit that is also high in antioxidants. Strawberries are also known to have anti-cancer properties due to their high content of ellagic acid and phenolic compounds. (Yilmaz, 2009). One of the most significant goals of sustainable agriculture is to save water and minimize the quantity of fertilizer used in many products, including strawberries, both to protect the environment and to reduce producers' input costs. Although research has been done on strawberry cultivation at different irrigation levels, there is a lack of information about the yield and fruit quality responses of strawberry species, particularly the changes in pomological characteristics as water availability decreases or increases. As a result, it's crucial to figure out how varied quantities of irrigation and various applications as ABA treatments affect the strawberry quality and yield.

Irrigation has been documented in different studies to have a major impact on strawberry plant growth and fruit yield (Serrano et al., 1992; Kruger et al., 1999; Yuan et al., 2004; Kapur et al., 2018a). Generally, it was observed that fruit weight and size had a positive correlation with the amount of irrigation water. In this regard, the majority of research reveal that irrigation method and irrigation water have a substantial impact on strawberry productivity. The development periods of the plant provide a lot of convenience in determining the irrigation times and irrigation intervals. However, in such studies, it's important to figure out how much and how water will be supplied during certain times, as well as the relationship between irrigation and fruit yield and quality. Thus, in addition to water consumption, it will be possible to determine the most appropriate irrigation program with an appropriate irrigation method (Kanber et al., 1986). Furthermore, there are few research analyzing the interaction of various irrigation regimes with treatments like Abscisic Acid, thus it's critical to conduct trials on this subject.

This study will contribute to water saving, which is very important in optimizing water consumption for the future of sustainable agriculture, as well as revealing the negativities of e-ISSN: 2148-2683 over-irrigation and insufficient irrigation. The goal of this research was to see how varying irrigation levels and $\mathrm{ABA}$ treatments affected strawberry yield and fruit quality.

\section{Material and Method}

This experimental study was conducted in the high tunnels of the experimental farm located in the University of Çukurova, Adana, Turkey (latitude: $36^{\circ} 59^{`} \mathrm{~N}$, longitude $35^{\circ} 27^{`} \mathrm{E}, 20 \mathrm{~m}$ asl). The climate of the study site is dry Mediterranean, and the clayey soils of the experimental plots are Xerofluvents with $1.6 \mathrm{~g} \mathrm{~cm}-1$ bulk density, $7.6 \mathrm{pH}$, and water contents of $36 \%$ and $16 \%$ for field capacity and wilting points respectively. The strawberry (Fragaria $x$ ananassa Duch) cultivar 'Rubygem' was planted on September 22 (referred to as 0 days after planting (DAP)) 2018 and cropping continued until June 19, 2019. The frigo type plants were used, Rubygem is famous for its earliness alongside its good taste and aroma. With a center height of $2.50 \mathrm{~m}$ and 0.8 $\mathrm{m}$ at the open sides ( $40 \mathrm{~m}$ long and $6.5 \mathrm{~m}$ wide), the high tunnel was composed of a steel frame covered in $0.1 \mathrm{~mm}$ thick transparent polyethylene (PE) film (Figure 1). A climate station was ( $2 \mathrm{~m}$ above soil surface) placed in the center of the high tunnel to monitor temperature and humidity. Solar radiation was used to heat the tunnel's interior.

The berries were planted in trapezoidal raised beds that were $0.70 \mathrm{~m}$ wide at the base, $0.50 \mathrm{~m}$ wide at the top, $0.30 \mathrm{~m}$ high, and $0.3 \mathrm{~m}$ apart. Each was mulched with a $0.05 \mathrm{~mm}$ thick, twosided polyethylene mulch cover with a grey upper side and a black underneath (in keeping with local cultural customs), and surface drip irrigation was connected along the center. Strawberries were planted in two rows, $0.3 \mathrm{~m}$ apart, with plants spaced $30 \mathrm{~cm}$ apart, for a total plant density of 6.65 plants per $\mathrm{m}^{2}$. There were four beds in each tube (Photo 1). After planting, adequate water was supplied until the plants had three trifoliate leaves. Drip irrigation was used to apply fertilizers consistently to each treatment, as it was the foliar application of agricultural pesticides to combat foliar and fruit diseases.

The trial was set up as a split-plot design with four replicates (blocks) totaling 32 plots, using a $4 \times 2$ factorial scheme of irrigation levels and ABA use. Applications (ABA usage and control) were planned and organized as subplots over the main plot and various irrigation regimes. Furthermore, approximately six months after planting, $20 \mu \mathrm{mol} \mathrm{L} \mathrm{L}^{-1}$ Abscisic Acid was sprayed three times (March 07, April 05, May 08, 2018) from March to May. The data was examined using JMP version 5.0.1, a statistical software (SAS Institute Inc., Cary, NC, USA). The effects of the irrigation regime and $\mathrm{ABA}$ on the measured parameters were determined using ANOVA to analyze the differences amongst groups, the Least Significant Difference test was used. Comparisons with a $\mathrm{P}$ value of less than 0.05 were ruled statistically significant. IR50, IR75, IR100, and IR125 were the four irrigation treatments, with water amounts applied of $0.5,0.75,1.00$, and 1.25 times pan evaporation (Epan). The Epan value was calculated using a typical $120.7 \mathrm{~cm}$ diameter and $25 \mathrm{~cm}$ depth US Weather Service Class A pan positioned over the crop canopy in the high tunnel's center. With 266 plants per plot, four irrigation treatments were installed in four beds of four, $10 \mathrm{~m}$ by $4 \mathrm{~m}$ plots. According to Kapur et al., the amount of irrigation was computed (2018b).

$I R=A \times E o \times K c p \times P$

$\mathrm{IR}=$ Irrigation water amount $(\mathrm{Lt})$ 
$\mathrm{Kcp}=$ crop pan coeficient

$\mathrm{P}=$ crop cover $(\%)$ (first 3 months 0.5 ; after 0.75 )

$\mathrm{Eo}=$ Evaporation from Class A pan (mm)

$\mathrm{A}=$ Area $(\mathrm{m} 2)$

Treatments IR125, IR100, IR75, and IR50 received a total of $712,575,438$, and $301 \mathrm{~mm}$ of water from the beginning to the completion of the experiment, respectively. In the trial period after applying different irrigation levels a total of 49 irrigation applications were made throughout the vegetation period.

From late February through June, mature strawberry fruits were collected twice a week. The total weight of fruits gathered from 10 plants chosen from each treatment was used to calculate the average fruit yield (g/plant). Weighing each fruit on each harvest day provided the mean fruit weight.

To define the quality of strawberry fruits some pomological analyses were made on April 3 times sampling via 10 days' intervals were done and the average values were evaluated as fruit brightness color (L Hunter lab, Minolta CR-300), fruit firmness (penetrometer, Turani, Italy, 0.1-2 Ib, Ib/inch2), soluble solids content (SSC, ATAGO ATC-1, Tokyo, Japonya, hand refractometer), $\mathrm{pH}$ of fruit juice (by the digital $\mathrm{pH}$ meter, Mettler Toledo, USA).

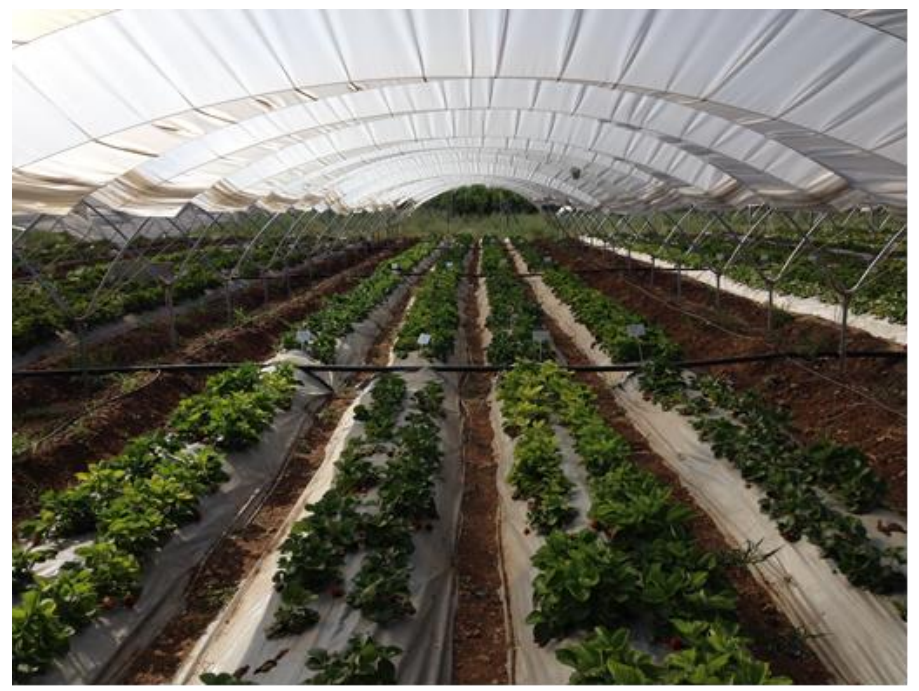

Figure 1: High Tunnel used in the experiment.

\section{Results and Discussion}

The effects of different irrigation levels (IR50, IR75, IR100, IR125) and $20 \mathrm{~mol} \mathrm{~L}^{-1} \mathrm{ABA}$ treatments on yield and fruit quality (pomological analyses; fruit exterior color, fruit firmness, SSC, $\mathrm{pH}$ content) in Rubygem strawberry cultivar were investigated.

During the research, a total of $712 \mathrm{~mm}$ irrigation water was given to the IR125 application, $575 \mathrm{~mm}$ to the IR100 application, $438 \mathrm{~mm}$ to the IR75 application, and $301 \mathrm{~mm}$ to the IR50 application. Previous studies with similar irrigation amounts have been conducted on strawberry plants using a wide variation of irrigation water from $250 \mathrm{~mm}$ to $825 \mathrm{~mm}$, and the irrigation levels of our study seem to be compatible with other studies. (Kapur et al., 2018a; Lozano et al., 2016; Kumar and Dey, 2011). One of the major factors limiting the growth of the strawberry plant is the ambient temperature. Strawberries are sensitive to extremes of temperature and cold, and the ideal temperature for plant growth is between 20 and $26^{\circ} \mathrm{C}$. The e-ISSN: 2148-2683 monthly average temperature, relative humidity, and solar radiation values of the in and out of the high tunnel in the study area are provided in Table 1 during the growing period.

The average air temperature inside the high tunnel was roughly $2.8^{\circ} \mathrm{C}$ higher during the day and $1.3^{\circ} \mathrm{C}$ lower at night, according to measurements of indoor and outdoor temperature, relative humidity, and solar radiation were recorded during the growing period. The highest average daytime indoor air temperature was observed in June $\left(31.18^{\circ} \mathrm{C}\right)$, and the lowest average daytime indoor air temperature was measured in January $\left(14.47^{\circ} \mathrm{C}\right)$ during the growing period. While the mean relative humidity indoors was lower than outside during the day, it was greater at night. The data obtained from the meteorological device showed that the radiation inside the tunnel was lower than outside, as expected. In addition, the highest solar radiation during the growing season was measured in June. Powell et al. (2013) found that high tunnels kept temperatures 3 to $4^{\circ} \mathrm{C}$ higher than the ambient temperature while maintaining identical relative humidity levels.

\subsection{Yield Per Plant (g/plant)}

The harvest of the Rubygem strawberry cultivar began on March 19, 2019 and lasted on June 20, 2019. The harvest took 94 days, with three-day intervals between two consecutive harvests. Table 2 shows the impact of varied irrigation levels and abscisic acid applications on the average yield values per plant in the trial year during the growing season.

The variations between the yield values per plant of different irrigation applications in the trial year were found to be statistically significant at the level of $1 \%$ in the Rubygem strawberry cultivar, which was studied during the growing season. The differences between the yield values per plant of ABA applications were found to be statistically insignificant in the trial year. Furthermore, irrigation $\mathrm{x}$ application interactions were shown to be statistically negligible depending on the variations of the yield.

When the average yield per plant of the Rubygem strawberry cultivar was examined, the highest average yield per fruit per plant was obtained with $1123.9 \mathrm{~g}$ /plant from the IR125 application, and the lowest fruit yield per plant was $471.9 \mathrm{~g} / \mathrm{plant}$ from the IR50 application in various irrigation water applications. The maximum average yield per plant from the ABA IR125 combination was $1124.5 \mathrm{~g} /$ plant, while the lowest average yield per plant from ABA IR50 was $655.1 \mathrm{~g} / \mathrm{plant}$ among the ABA-treated plants. Abscisic acid-treated plants produced $66.3 \mathrm{~g}$ higher per plant than control plants, while being statistically insignificant.

Similarly, Ağır and Saner (2014) found that the yield per plant was 500 (g/plant) as a result of their studies on strawberries. Adak and Pekmezci (2011) reported that the yield per plant was 463 (g/plant) in frigo type plants and 345 (g/plant) in rooted-type plants in their study on the effect of different plant types and growing media on soilless culture strawberry cultivation. In a study conducted in Erzurum ecology to determine the performance of certain strawberry species (Fragaria $\mathrm{x}$ ananassa Duch.), the Rubygem cultivar had the lowest yield per plant in the trial year of the plants in the plot, while the Kabarla cultivar had the highest output (296.2 g/plant) has been established. In previous studies on different strawberry cultivars, Gündüz and Özdemir (2012) yield per plant Cal Giant (528.7 g), Sweet Charlie (647.8 g), Camarosa (595.9 g), Macit et 
al., (2011) Kabarla (561.56 g), Sweet Charlie (428.64 g), Camarosa (569.65 g), Festival (400.82 g), While Özdemir et al., (2001) were observed as $579.8 \mathrm{~g} / \mathrm{plant}$ for Camarosa, 620.2 $\mathrm{g} /$ plant for Pajaro (, $554.4 \mathrm{~g} /$ plant for Sweet Charlie. On the other side, Çeliktopuz (2019) Rubygem (801 g/plant), Kabarla (579 g/plant), and Kaleci and Gunay (2006) Tadla (307 g/plant), Camarasa varieties (280 g/plant) reported that they obtained. Strawberry yield was reported to be significantly reduced under water stress by Liu et al., (2007), Ghaderi et al., (2015), and Hoppula and Salo (2007). When compared to earlier research, it was revealed that our study had a better yield per plant under the optimum condition. In this context, it has been determined that differences in the research area's meteorological conditions, irrigation levels, and agricultural techniques have an impact on these values. Thus, it is anticipated that such studies will help identify the most effective practices.

\subsection{Average Fruit Weight (g/fruit)}

Differences between irrigation practices were found to be statistically significant at the $1 \%$ level in terms of average fruit weight. The application and interaction of these factors were found to be statistically insignificant on average fruit weight.

Among the irrigation applications, the IR125 application produced the highest average fruit weight value of $26.8 \mathrm{~g} /$ fruit, while the IR50 application produced the lowest average fruit weight value of $16.7 \mathrm{~g} /$ fruit. The highest average fruit weight was $28.4 \mathrm{~g}$ /fruit from ABA x IR125 combination, and the lowest average fruit weight was observed as $17.1 \mathrm{~g} /$ fruit from $\mathrm{ABA} \times$ IR50 among the plants treated with ABA. ABA-treated plants produced $1.3 \mathrm{~g} /$ fruit higher average fruit weight than control plants, despite the fact that the difference was not statistically significant. The similar results were observed by Çeliktopuz (2019) at Rubygem cultivar $17.4 \mathrm{~g} /$ fruit, Kabarla $13.5 \mathrm{~g} /$ fruit and Macit et al., (2011) determined as 10.09, 9.95, and $9.27 \mathrm{~g} / \mathrm{plant}$ for the Redlans Hope, Camarosa, and Kabarla cultivars, respectively. When compared to previous studies, it is seen that the average fruit weight is higher in our study. These variations are assumed to be due to water use efficiency and the Rubygem strawberry cultivar's morphological and physiological good responses to stress. 


\section{Avrupa Bilim ve Teknoloji Dergisi}

Table 1. Average monthly air temperature, relative humidity, and solar radiation values inside and outside the tunnel during the 20182019 growing season

\begin{tabular}{|c|c|c|c|c|c|c|c|c|c|c|}
\hline \multirow[t]{2}{*}{ Months } & \multicolumn{2}{|c|}{$\begin{array}{c}\text { Day time } \\
\text { average temperature } \\
\left({ }^{\circ} \mathrm{C}\right)\end{array}$} & \multicolumn{2}{|c|}{$\begin{array}{c}\text { Nighttime } \\
\text { average temperature } \\
\left({ }^{\circ} \mathrm{C}\right)\end{array}$} & \multicolumn{2}{|c|}{$\begin{array}{l}\text { Day time } \\
\text { relative humidity } \\
(\%)\end{array}$} & \multicolumn{2}{|c|}{$\begin{array}{l}\text { Nighttime } \\
\text { relative humidity } \\
(\%)\end{array}$} & \multicolumn{2}{|c|}{$\begin{array}{l}\text { Average solar radiation } \\
\left(\mathrm{W} / \mathrm{m}^{2}\right)\end{array}$} \\
\hline & Inside & Outside & Inside & Outside & Inside & Outside & Inside & Outside & Inside & Outside \\
\hline October, 2018 & 25.14 & 21.92 & 16.69 & 17.87 & 52.16 & 55.67 & 85.25 & 71.55 & 371.00 & 480.60 \\
\hline November, 2018 & 21.05 & 18.76 & 11.83 & 13.45 & 48.20 & 52.08 & 79.00 & 75.44 & 322.27 & 490.50 \\
\hline December, 2018 & 17.10 & 14.55 & 8.80 & 10.55 & 57.45 & 60.35 & 86.32 & 82.55 & 244.00 & 470.80 \\
\hline January, 2019 & 14.47 & 12.65 & 7.22 & 8.71 & 62.08 & 64.52 & 84.70 & 78.35 & 239.84 & 467.00 \\
\hline February, 2019 & 18.54 & 16.09 & 9.53 & 11.11 & 54.89 & 58.35 & 86.02 & 78.64 & 338.75 & 673.81 \\
\hline March, 2019 & 22.08 & 19.09 & 12.05 & 13.61 & 54.61 & 58.39 & 87.48 & 79.89 & 437.29 & 859.77 \\
\hline April, 2019 & 26.47 & 22.67 & 14.14 & 15.38 & 44.07 & 49.00 & 79.54 & 74.54 & 497.57 & 946.93 \\
\hline May, 2019 & 29.37 & 26.26 & 19.06 & 20.20 & 49.01 & 53.07 & 81.84 & 74.97 & 515.48 & 1012.55 \\
\hline June, 2019 & 31.18 & 28.19 & 21.72 & 22.49 & 53.50 & 57.91 & 86.79 & 80.80 & 524.18 & 1020.55 \\
\hline
\end{tabular}

Table 2. The effects of four different irrigation regimes and abscisic acid treatments on the average yield per plant during the growing season of Rubygem strawberry cultivar ( $\mathrm{g} /$ plant)

\begin{tabular}{|c|c|c|c|c|c|c|}
\hline \multirow{6}{*}{ 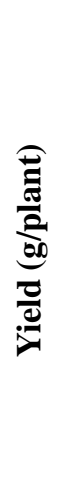 } & \multirow{2}{*}{ Application } & \multicolumn{4}{|c|}{ Irrigation Level } & \multirow[t]{2}{*}{ Application average } \\
\hline & & IR50 & IR75 & IR100 & IR125 & \\
\hline & Control & 471.9 & 699.1 & 1002.7 & 1123.4 & 824.3 \\
\hline & $\mathbf{A B A}$ & 655.1 & 785.3 & 997.6 & 1124.5 & 890.6 \\
\hline & Irrigation Average & $\begin{array}{c}563.5 \\
C\end{array}$ & $\begin{array}{c}742.3 \\
B\end{array}$ & $\begin{array}{c}1000.1 \\
A\end{array}$ & $\begin{array}{c}1123.9 \\
A\end{array}$ & \\
\hline & \multicolumn{6}{|c|}{ LSDirr $* * *=152.22$} \\
\hline \multicolumn{7}{|c|}{ Different letters were used to show differences in the means. } \\
\hline
\end{tabular}




\subsection{Fruit Quality Parameters}

The fruit quality parameters were obtained April harvested fruit due to the highest yield were obtained in this month under Mediterranean region of Turkey.

\subsubsection{Fruit Color $\left(L^{*}\right)$}

Strawberry fruit color is one of the most important quality indicators. The color of the strawberry that is being supplied to the consumer attracts them as an indicator of market maturity and quality. In strawberry cultivation, these fruits are desired to be bright red for fresh consumption and dark red in flesh color to be used in industry (Kaşka et al.,1986).

The $\mathrm{L}^{*}$ represents the dark and brightness of the fruit. Table 4 reflects the average fruit exterior color $\mathrm{L}$ values of the Rubygem strawberry cultivar under irrigation and ABA applications. All factor and their interaction were found to be statistically negligible variations in $\mathrm{L}^{*}$ values.

The highest $L^{*}$ value was obtained from the IR75 application $\left(38.3^{*}\right)$ according to irrigation applications, while the lowest $\mathrm{L}$ value was found in the IR125 application $\left(36.5^{*}\right)$. Regarding the ABA-treated plants, the highest $\mathrm{L}^{*}$ value was obtained from the ABA x IR100 application (39.0*) and the lowest $\mathrm{L}^{*}$ value was obtained from the ABA x IR125 application (37.0*). The ABA-treated plants had 0.8 higher $\mathrm{L}^{*}$ values than the control plants. In this context, it was determined that ABA increased the quality in terms of color, even though there was no statistical difference. In addition, the lowest $\mathrm{L}^{*}$ values were determined in the application with the highest irrigation water, albeit insignificant.

Generally, our results were lined with Kaleci \& Günay (2006) found that fruit outer color values were 50* in Tudla; $35^{*}$ in Camarosa, Elvira, Delmarvel, Annapolis varieties; and 20* in Evita and Elsanta cultivars. In other studies, Adak (2010) determined that the outer color $\mathrm{L}^{*}$ values of the fruit varied between $31.87 *$ and $33.12 *$ in their study on strawberries. The findings of these studies appear to be consistent with the findings of our investigation.

\subsubsection{Fruit Firmness (Newton)}

Genetic characteristics and growing conditions can be effective in establishing different quality criteria such as fruit firmness. Some farming practices, inputs, and harvest time are examples of these factors. The fruit firmness values in April were measured and the average fruit firmness values obtained are presented in Table 5.

In the trial year, the changes in fruit firmness values between various irrigation water applications, ABA application, and irrigation $\mathrm{x}$ application interaction were shown to be statistically insignificant.

Although there was no statistically significant difference in average fruit firmness at the combination between ABA and irrigation applications in the Rugygem strawberry cultivar, the fruit flesh firmness ranged between $1.0 \mathrm{lb} / \mathrm{inch} 2$ and $1.1 \mathrm{lb} / \mathrm{inch}^{2}$.

Kaşka et al., (1986) stated in their study on a strawberry that the firmness of the fruit pulp is the most important quality factor in fruit production. The firmness of the strawberry fruits decreases by improving maturity. In a comparable study, Sarıdaş et al., (2019) discovered that the Albion cultivar (1.09 lb/inch2) had the maximum fruit firmness, while the Sevgi cultivar had the lowest fleshy firmness $(0.47 \mathrm{lb} / \mathrm{inch} 2)$. The study conducted by Gündüz \& Özdemir (2012) examine the effects of different growing areas and genotypes on the firmness of fruit, and Camarosa (0.71 kg-k), Carmine (0.67 kg-k), and Kabala (0.67 kg-k) genotypes produced the hardest fruits among the genotypes, while the Osmanl cultivar yielded the softest fruits $(0.22 \mathrm{~kg}-\mathrm{k})$.

\subsubsection{Soluble Solid Contents $(\%)$}

The results of SSC of Rubygem fruits were shown in Table 6. All factors and their interaction were found to be statistically significant at the $1 \%$ level.

The amount of SSC was found to vary between $7.6 \%$ and $10.4 \%$ during the experiment. In irrigation applications, the IR50 application had the greatest contribution SSC value of $9.2 \%$, while the IR125 application had the lowest at $7.6 \%$. In abscisic acid applications, the highest SSC value was obtained from the ABA x IR50 application, $10.4 \%$, and the lowest was $7.7 \%$ in the ABA $x$ IR125, ABA x IR100 applications. In this context, it is expected that SSC will increase as the amount of irrigation decreases.

Our results generally in line with Özbahçeli and Aslantaş (2015) who discovered that the SSC value varied between $7.3 \%$ (Kabarla) and $9.5 \%$ (Rubygem) among cultivars.

When abscisic acid and irrigation interactions are compared, the highest SSC value was determined as $10.4 \%$ in ABA x IR50 application and the lowest SSC value was determined as $7.6 \%$ in IR125 application. Overall, ABA-treated plants had 0.6 percent more SSC than control plants, according to this study. In this context, it was determined that $\mathrm{ABA}$ raised $\mathrm{SSC}$, which is an important quality parameter. 
Table 3. The effects of four different irrigation levels and ABA applications on the average fruit weight (g/fruit) of Rubygem strawberry during the growing season

\begin{tabular}{|c|c|c|c|c|c|c|}
\hline \multirow{6}{*}{ 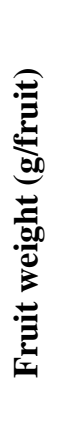 } & \multirow{2}{*}{ Application } & \multicolumn{4}{|c|}{ Irrigation levels } & \multirow{2}{*}{$\begin{array}{c}\text { Application } \\
\text { average }\end{array}$} \\
\hline & & IR50 & IR75 & IR100 & IR125 & \\
\hline & Control & 16.7 & 20.1 & 22.5 & 26.8 & 21.5 \\
\hline & ABA & 17.1 & 21.6 & 23.9 & 28.4 & 22.8 \\
\hline & Irrigation average & $16.9 \mathrm{C}$ & $20.9 B$ & $23.2 B$ & $27.6 \mathrm{~A}$ & \\
\hline & & $* * *=2.8$ & LSDa & & app $=1$ & \\
\hline & & $\begin{array}{l}\text { erent let } \\
\text { Not Sig }\end{array}$ & $\begin{array}{l}\text { used to } \\
* * *: p<<\end{array}$ & $\begin{array}{l}\text { ferences } \\
*: p<0 .\end{array}$ & $\begin{array}{l}\text { eans. } \\
0.05 \text {. }\end{array}$ & \\
\hline
\end{tabular}

Table 4: The effects of different irrigation levels and ABA applications on fruit outer color of Rubygem strawberry cultivar ( $\left.L^{*}\right)$

\begin{tabular}{|c|c|c|c|c|c|c|}
\hline \multirow{6}{*}{ 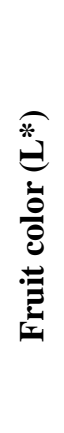 } & \multirow{2}{*}{ Application } & \multicolumn{4}{|c|}{ Irrigation levels } & \multirow{2}{*}{$\begin{array}{c}\text { Application } \\
\text { average }\end{array}$} \\
\hline & & IR50 & IR75 & IR100 & IR125 & \\
\hline & Control & 37.3 & 38.3 & 37.2 & 36.5 & 37.3 \\
\hline & $\mathbf{A B A}$ & 38.5 & 38.00 & 39.00 & 37.00 & 38.1 \\
\hline & Irrigation average & 37.9 & 38.2 & 38.1 & 36.7 & \\
\hline & & $r^{*}=1.37$ & LSDap & & $\mathbf{p}=\mathbf{N} . \mathbf{S}$. & \\
\hline & & $\begin{array}{l}\text { erent lett } \\
\text { Not Sigı }\end{array}$ & $* *: p<$ & $\begin{array}{l}\text { erences i } \\
: \mathrm{p}<0.0\end{array}$ & & \\
\hline
\end{tabular}

Table 5: The effects of different irrigation levels and abscisic acid applications on fruit flesh firmness during the growing period of Rubygem strawberry cultivar (lb/inch ${ }^{2}$ )

\begin{tabular}{|c|c|c|c|c|c|c|}
\hline \multirow{6}{*}{ 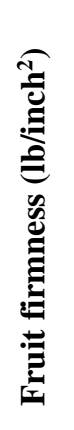 } & \multirow{2}{*}{ Application } & \multicolumn{4}{|c|}{ Irrigation level } & \multirow{2}{*}{$\begin{array}{c}\text { Application } \\
\text { average }\end{array}$} \\
\hline & & IR50 & IR75 & IR100 & IR125 & \\
\hline & Control & 1.00 & 1.00 & 1.1 & 1.00 & 1.0 \\
\hline & $\mathbf{A B A}$ & 1.00 & 1.00 & 1.1 & 1.1 & 1.1 \\
\hline & Irrigation average & 1.00 & 1.00 & 1.1 & 1.1 & \\
\hline & & $r=\mathbf{N} . \mathbf{S}$ & LSDap & LS & $p=$ N. S. & \\
\hline & & $\begin{array}{l}\text { rent lett } \\
\text { Not } \mathrm{Sig}\end{array}$ & $\begin{array}{l}\text { used to } \\
* * *: p<<\end{array}$ & $\begin{array}{l}\text { erences in } \\
: p<0.01\end{array}$ & $\begin{array}{l}\text { ns. } \\
0.05 .\end{array}$ & \\
\hline
\end{tabular}

\subsection{4. pH Content}

The differences between the $\mathrm{pH}$ values of different irrigation applications in the Rubygem strawberry cultivar were found to be statistically significant at the level of $5 \%$ in the trial year, while the differences between the $\mathrm{pH}$ values of abscisic acid applications were found to be statistically insignificant. In addition, the differences arising from the interaction between irrigation $\mathrm{x}$ application interaction were found to be statistically insignificant in the trial year (Table 7).
It was determined that the $\mathrm{pH}$ values varied between 3.86 and 4.0. The greatest $\mathrm{pH}$ value was determined as 4.0 from the IR50 application, while the lowest $\mathrm{pH}$ value was determined as 3.86 from the IR125 treatment in irrigation applications. The greatest $\mathrm{pH}$ value with abscisic acid treatments was 3.98 in the ABA x IR50 application, while the lowest $\mathrm{pH}$ value was 3.92 in the ABA $x$ IR125 application. 
Table 6: The effects of different irrigation levels and abscisic acid applications on the SSC (\%)

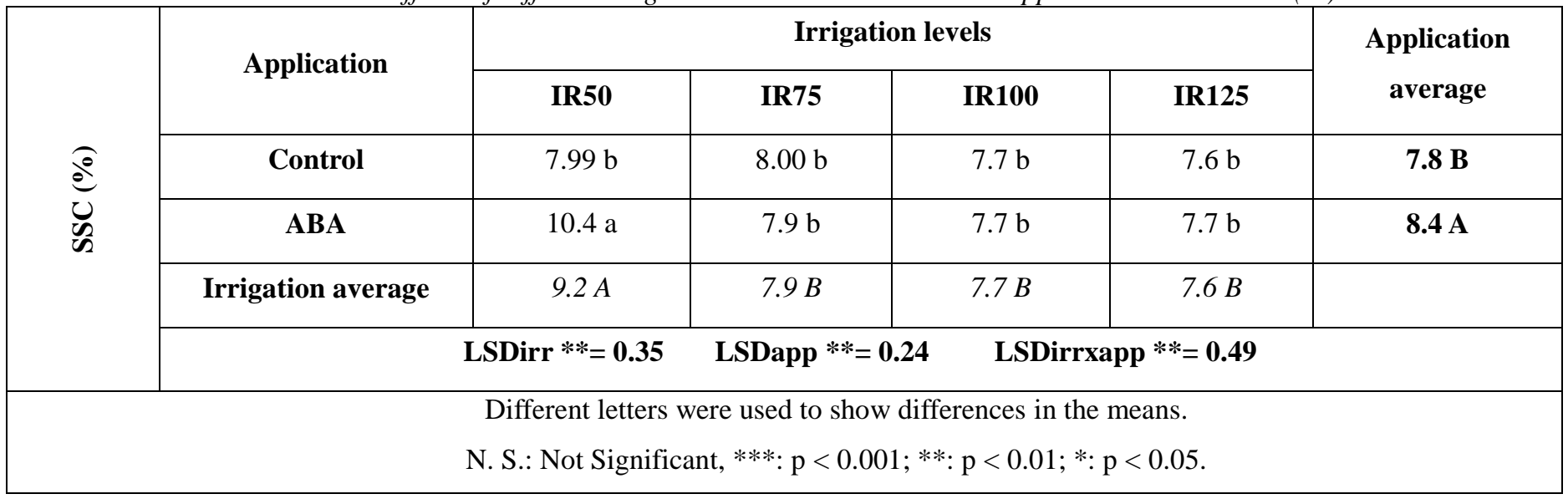

Table 7: Effects of different irrigation levels and abscisic acid applications on pH in Rubygem strawberry cultivar.

\begin{tabular}{|c|c|c|c|c|c|c|}
\hline \multirow{6}{*}{ 줄 } & \multirow{2}{*}{ Application } & \multicolumn{4}{|c|}{ Irrigation levels } & \multirow{2}{*}{$\begin{array}{c}\text { Application } \\
\text { average }\end{array}$} \\
\hline & & IR50 & IR75 & IR100 & IR125 & \\
\hline & Control & 4.0 & 3.96 & 3.88 & 3.86 & 3.9 \\
\hline & $\mathbf{A B A}$ & 3.98 & 3.95 & 3.93 & 3.92 & 3.9 \\
\hline & Irrigation average & $3.99 A$ & $3.95 A B$ & $3.90 B$ & $3.89 B$ & \\
\hline & \multicolumn{5}{|c|}{ LSDirr $*=0.06$} & \\
\hline & & $\begin{array}{l}\text { erent let } \\
\text { Not Sig }\end{array}$ & $\begin{array}{l}\text { used to } \mathrm{s} \\
* * *: \mathrm{p}<0\end{array}$ & $\begin{array}{l}\text { rences i } \\
p<0.0\end{array}$ & $\begin{array}{l}\text { ans. } \\
0.05 \text {. }\end{array}$ & \\
\hline
\end{tabular}

\section{Conclusions and Recommendations}

Regarding plant yields, the irrigation subjects in IR125, IR100, IR75, and IR 50 were divided into various statistical groups. The highest average yield per plant was obtained from ABA x IR125 application with 1124.5 (g/plant). It was determined that the abscisic acid application increased the yield by approximately $8 \%$, although it was not statistically significant compared to the control conditions. On the other hand, abscisic acid applications had no statistically significant influence on $\mathrm{pH}$, fruit color, fruit firmness, or fruit weight parameters, while a statistically significant effect on SSC parameters. As a result of the effects of $\mathrm{ABA}$ on plant growth, $\mathrm{ABA}$ treatments may be an essential method for improving fruit quality in water-stressed areas. Although the most severe water stress, IR50, had a favorable effect on $\mathrm{pH}$ and SSC, it was discovered that extreme water stress had a detrimental effect, particularly on fruit weight per plant and fruit quantity per plant.

Based on the findings of the study, it is expected that the IR125 and IR100 irrigation regimes could be applied more frequently in future investigations. Furthermore, the findings suggest that combining ABA with the proper amount of irrigation water, as well as ABA applications in water stress or multiple stress circumstances, may be useful in increasing plant adaptation to some extent. In this case, between 575 and $712 \mathrm{~mm}$ irrigation water applications with ABA application are advised for optimum yield when strawberries are grown in high tunnels in the Mediterranean environment.

\section{Acknowledge}

The Coordination Unit of Scientific Research Projects at Çukurova University provided financial assistance for this research through the project FYL-2018-11307.

\section{References}

Adak, N., \& Pekmezci, M. (2011). Farklı fide tipleri ve yetiştirme ortamlarının topraksız kültür çilek yetiştiriciliği üzerine etkileri. Journal of Agricultural Sciences. 17: 269-278

Adak, N. (2010). Camarosa çilek çeşidinde değişik EC düzeylerinin verim ve kalite üzerine etkileri. Derim, 27(2), 22-33.

Ağaoğlu, S. Y., \& Gerçekçioğlu, R. (2013). Üzümsü Meyveler. Tomurcuk Ltd. ġti. Eğitim Yayınları, No: 1. Ders Kitabı, Ankara, 55-115.

Ağır, H. B., \& Saner, G. (2014). İzmir İli Emiralem Beldesinde Açıkta ve Örtüaltı Çilek Yetiştiriciliğinde Üretim Maliyetlerinin Belirlenmesi. Ege Üniversitesi Ziraat Fakültesi Dergisi, 51(2), 145-152.

Çeliktopuz, E. (2019). Farkli Sulama Düzeyleri ve Biyoaktivatör Uygulamasinin İki Çilek Çeşidinde Verim Ve Meyve Kalitesi İle Besin Elementi İçerikleri Üzerine Etkisinin Belirlenmesi. Çukurova Üniversitisi Fen Bilimleri Enstitüsü. Tarımsal Yapılar ve Sulama Anabilim Dalı, Doktora Tezi, Adana. 
Ghaderi, N., Normohammadi, S., \& Javadi, T. (2015). Morphophysiological responses of strawberry (Fragaria $\times$ ananassa) to exogenous salicylic acid application under drought stress. Journal of Agricultural Science and Technology, 17(1), 167178.

Gündüz, K., \& Özdemir, E. (2012). Farklı yetiştirme yerlerinin bazı çilek genotiplerinin erkencilik indeksi, verim ve meyve kalite özellikleri üzerindeki etkileri. Ege Üniversitesi Ziraat Fakültesi Dergisi, 49(1), 27-36.

Hoppula, K. I., \& Salo, T. J. (2007). Tensiometer-based irrigation scheduling in perennial strawberry cultivation. Irrigation Science, 25(4), 401-409.

Kaleci, N., \& Günay, S. (2006). Çanakkale Koşullarinda Yetiştirilen Bazi Çilek Çeşitlerinin Fenolojik, Pomolojik Ve Verim Özelliklerinin Belirlenmesi. Bahçe, 35(1), 47-54.

Kanber, R., Eylen, M., \& Tok, A. (1986). Çukurova Koşullarında Karık ve Damla Sulama Yöntemleri İle Sulanan Çileğin Verim ve Su Tüketimi. Tarsus Köy Hizmetleri Araştırma Enstitüsü Yayınları. Genel Yayın, (135).

Kapur, B., Celiktopuz, E., Saridas, M. A., \& Karg1, S. P. (2018a). Irrigation Regimes and Bio-stimulant Application Effects on Yield and Morpho-Physiological Responses of Strawberry. Horticultural Science and Technology, 36(3), 313-325.

Kapur, B., Sarıdaş, M. A., Çeliktopuz, E., Kafkas, E., \& Kargı, S. P. (2018b). Health and taste related compounds in strawberries under various irrigation regimes and biostimulant application. Food Chemistry, 263, 67-73.

Kaşka, N., Yıldız, A., Paydaş, S., Biçici, M., Türemiş, N., \& Küden, A. (1986). Türkiye için yeni bazı çilek çeşitlerinin Adana'da yaz ve kış dikim sistemleriyle örtü altında yetiştiriciliğinin verim, kalite ve erkencilik üzerine etkileri. Doğa Bilim Dergisi, 10(1), 84-102.

Krüger, E., Schmidt, G., \& Brückner, U. (1999). Scheduling strawberry irrigation based upon tensiometer measurement and a climatic water balance model. Scientia Horticulturae, 81, 409-424.

Kumar, S., \& Dey, P. (2011). Effects of different mulches and irrigation methods on root growth, nutrient uptake, wateruse efficiency and yield of strawberry. Scientia Horticulturae, 127(3), 318-324.

Liu, F., Savić, S., Jensen, C. R., Shahnazari, A., Jacobsen, S.-E., Stikić, R., \& Andersen, M. N. (2007). Water relations and yield of lysimeter-grown strawberries under limited irrigation. Scientia Horticulturae, 111(2), 128-132.

Lozano, D., Ruiz, N., \& Gavilán, P. (2016). Consumptive water use and irrigation performance of strawberries. Agricultural Water Management, 169, 44-51.

Maas, J. L., Wang, S.Y., \& Galleta, G. J. (1996). Heath Enhancing Properties of Strawberry Fruit, in: Pritts, M.P., Chandler, C.K. and C Rocker, T.E. (eds). Proceeding of the V North American Strawberry Conference, Orlando, Florida, 11-18.

Macit, İ., Koç, A., Güler, S., \& Deligöz, İ. (2011). Karadeniz Bölgesinde organik çilek yetiştiriciliği. Organik Tarım Araştırma Sonuçları, TC Tarım ve Köyişleri Bakanlığı, Tarımsal Araştırmalar Genel Müdürlüğü, 87-94.

Özbahçali, G., \& Aslantaş, R. (2015). Bazı Çilek Çeşitleri (Fragaria X ananasss Duch.)'nin Erzurum Ekolojisindeki Performanslarının Belirlenmesi. Atatürk Üniversitesi Ziraat Fakültesi Dergisi, 46(2), 75-84.

Özdemir, E., Gündüz, K., \& Bayazit, S. (2001). Tüplü taze fideyle yüksek tünelde yetiştirilen bazı çilek çeşitlerinin
Amik ovası koşullarında verim, kalite ve erkencilik durumlarının belirlenmesi. Bahçe, 30(1-2), 65-70.

Powell, M., Cowan, J., Miles, C., \& Inglis, D. A. (2013) Effect of a high tunnel, organic cropping system on lettuce diseases in western Washington. Online. Plant Health Progress. doi:10.1094/PHP-2013-0922-01-RS.

Sarıdaş, M. A., Bircan, M., Karaşahin, Z., Kafkas, E., \& Kargı, S. P. (2019). Melezleme Islahı ile Seçilmiş Çilek Genotiplerinde Bazı Pomolojik Özelliklerin Aktif Hasat Sezonu Boyunca Değişimi. Yüzüncü Yıl Üniversitesi Tarım Bilimleri Dergisi, 29(3), 506-515.

Serrano, L., Carbonell, X., Save, R., Marfà, O., Penuelas, J. (1992). Effects of irrigation regimes on the yield and water use of strawberry. Irrigation Science,13, 45-48. doi:10.1007/BF00190244.

Yılmaz, H. (2009). Çilek. Hasad Yayıncılık: 348, İstanbul.

Yuan, B., Sun, J., \& Nishiyama, S. (2004). Effect of drip irrigation on strawberry growth and yield inside a plastic greenhouse. Biosystems Engineering, 87(2), 237-245. 